\title{
Carbamazepine-Induced Pure Red Cell Aplasia
}

\author{
C. A. Mansoor ${ }^{1}$ Laksmi Priya $^{2}$ \\ ${ }^{1}$ Department of General Medicine, M.E.S. Medical College, \\ Perinthalmanna, Kerala, India \\ ${ }^{2}$ Department of Pathology, M.E.S. Medical College, Perinthalmanna, \\ Kerala, India \\ Int J Epilepsy 2018;5:50-52
}

\begin{abstract}
Address for correspondence C. A. Mansoor, MD, Department of General Medicine, M.E.S. Medical College, Perinthalmanna 679338 , Kerala, India (e-mail: drcamans@gmail.com).
\end{abstract}

\begin{abstract}
Keywords

- antiepileptic therapy

- carbamazepine

- pure red cell aplasia

Antiepileptic therapy is associated with various hematologic disorders. Pure red cell aplasia (PRCA) is a rare disease that may be congenital or acquired. Severe normocytic anemia, reticulocytopenia, and absence of erythroblasts from an otherwise normal bone marrow should raise the suspicion of PRCA. A 32-year-old unmarried woman was admitted with fatigue for 4 months. She had been on carbamazepine therapy for 4 years (200 mg twice daily) for seizure disorder. On evaluation, she was diagnosed to have PRCA secondary to carbamazepine. We describe a patient with carbamazepine-induced PRCA that improved after discontinuation of the drug.
\end{abstract}

\section{Introduction}

Pure red cell aplasia (PRCA) is a relatively rare disease. Acquired PRCA is usually transient when compared with the congenital variety. Acquired PRCA can be associated with malnutrition, drugs, toxins, and infections. Carbamazepine $\left(\mathrm{C}_{15} \mathrm{H}_{12} \mathrm{~N}_{2} \mathrm{O}\right)$ is a tricyclic compound that is most efficient against partial seizure with or without secondary generalization. Carbamazepine is known to cause a variety of hematologic abnormalities.

\section{Case}

A 32-year-old unmarried woman was admitted with fatigue for 4 months. She denied history of fever, weight loss, loss of appetite, bleeding manifestations, high-risk behavior, had no sick contacts, and had no history of addictions. She had been on carbamazepine therapy for 4 years (200 mg twice daily) for seizure disorder. She had severe pallor but had no lymphadenopathy or hepatosplenomegaly.

Hemoglobin was $4.5 \mathrm{~g} / \mathrm{dL}$ (normocytic and normochromic), total leucocyte count $6,500 / \mathrm{mL}$ with $64 \%$ neutrophils, and

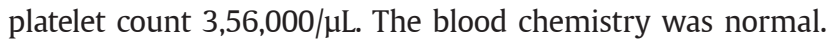
Peripheral smear showed predominantly normocytic normochromic red blood cells with scattered microcytes and macrocytes (-Fig. 1). White blood cells and platelets were adequate. Absolute reticulocyte count was $0.3 \%$ and reticulocyte index was 0.13 . Stool occult blood was negative and had no ova or cyst. Iron studies were normal (serum iron was
$164 \mu \mathrm{g} / \mathrm{dL}$, total iron-binding capacity $294 \mu \mathrm{g} / \mathrm{dL}$, and serum ferritin $401 \mathrm{ng} / \mathrm{mL}$ ). Human immunodeficiency virus (HIV), hepatitis $B$, and hepatitis $C$ serologies were negative. Serum vitamin $B_{12}$ and folic acid were normal. Bone marrow trephine biopsy showed marked erythroid hypoplasia with normal myeloid and megakaryocyte maturation. There was no marrow fibrosis on reticulin staining, and immunohistochemistry for E-cadherin for identifying the erythroid lineage showed positivity in few cells confirming marked erythroid hypoplasia (-Fig. 2). The patient was diagnosed to have PRCA as there was normocytic normochromic anemia, with a very low reticulocyte count, marked erythroid hypoplasia, without evidence of hemolysis and normal leucocyte and platelet counts. The

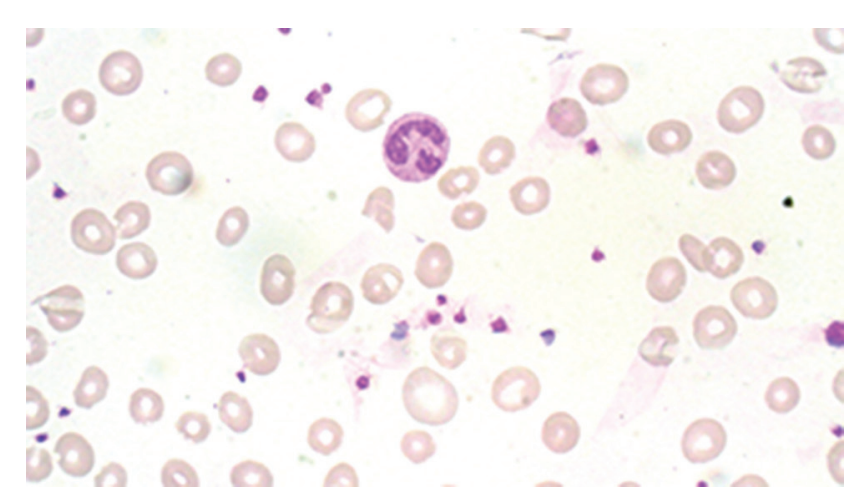

Fig. 1 Peripheral smear showing predominantly normocytic normochromic red blood cells with scattered microcytes and macrocytes (hematoxylin and eosin staining).
DOI https://doi.org/

$10.1055 / \mathrm{s}-0038-1657851$. ISSN 2213-6320.
License terms

(ㅇ) (1) $\ominus \circledast$ 


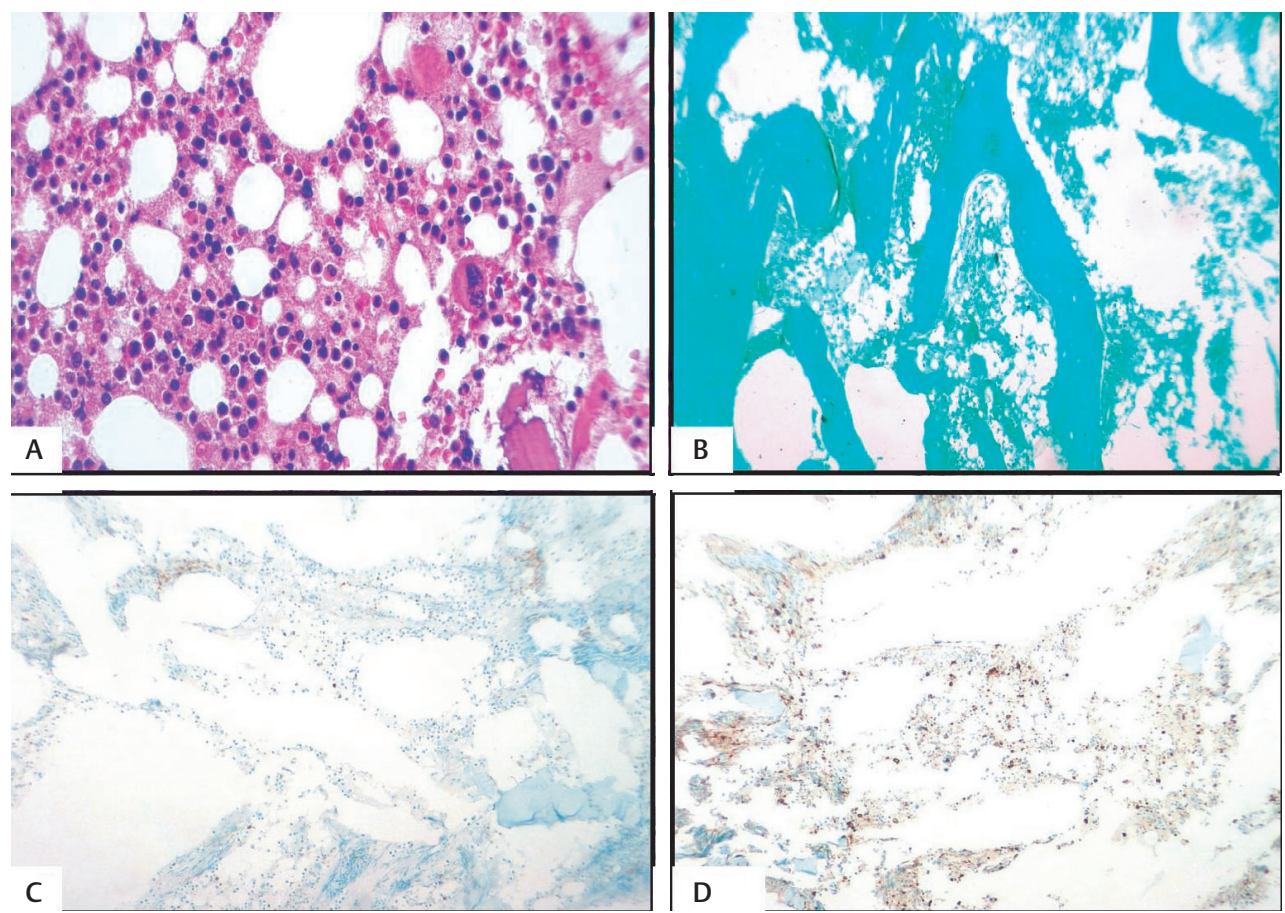

Fig. 2 (A) Bone marrow trephine biopsy showing marked erythroid hypoplasia with normal myeloid and megakaryocyte maturation and mild lymphocytic infiltration. (B) Reticulin showing no fibrosis in the marrow. (C) Immunohistochemistry for E-cadherin showing positivity in very few cells. (D) Immunohistochemistry for CD45 highlighting the mild lymphocytic infiltration (hematoxylin and eosin staining).

Naranjo adverse drug reactions probability score was 10, suggesting that carbamazepine was the probable cause for PRCA. Carbamazepine was discontinued and patient was started on levetiracetam $500 \mathrm{mg}$ three times daily for seizure. She also received packed cell transfusions. When reviewed after 3 months, she was asymptomatic and hemoglobin was $11.5 \mathrm{~g} / \mathrm{dL}$.

\section{Discussion}

Pure red cell aplasia is a rare disease and may be congenital or acquired. Severe normocytic anemia, reticulocytopenia, and absence of erythroblasts from an otherwise normal bone marrow should raise the suspicion of PRCA. ${ }^{1}$ Acquired PRCA is usually transient in nature in contrast to the congenital variety. Acquired PRCA can be associated with drugs, toxins, and infectious agents or from unknown causes.

Several mechanisms are postulated in the pathogenesis of drug-induced PRCA, including toxic interference by drugs with the metabolism of nucleated red cells, immunologically mediated reaction with antibodies formed against red cell precursors, and specific inhibitory effect on DNA synthesis probably at the step of deoxyriboside formation. ${ }^{2}$ Drug-induced PRCA is reversible after discontinuation of the offending drug.

Antiepileptics such as diphenylhydantoin, sodium valproate, and carbamazepine were previously reported to be associated with PRCA..$^{3-5}$ Drugs can be responsible for various red blood cell-related syndromes, including hemolytic anemia, methemoglobinemia, PRCA, sideroblastic anemia, megaloblastic anemia, and polycythemia.
Pure red cell aplasia is an uncommon complication of carbamazepine therapy. PRCA after carbamazepine therapy was previously reported in a 2-year-old boy after 6 months at a daily dose of $10 \mathrm{mg} / \mathrm{kg}$. It resolved following discontinuation of carbamazepine. ${ }^{4}$ Few more cases of carbamazepineinduced PRCA were reported previously in the literature..$^{6-9}$ We present this case to make the readers aware of an extremely rare complication related to carbamazepine, which is reversible with discontinuation of the drug.

\section{Funding}

None.

\section{Conflict of Interest}

None.

\section{References}

1 Sawada K, Fujishima N, Hirokawa M. Acquired pure red cell aplasia: updated review of treatment. $\mathrm{Br} \mathrm{J}$ Haematol 2008;142(4):505-514

2 Dixit R, Dixit R, Dixit K. Isoniazid induced pure red cell aplasia. Indian J Allergy Asthma Immunol 2003;17:93-95

3 Bartakke S, Abdelhaleem M, Carcao M. Valproate-induced pure red cell aplasia and megakaryocyte dysplasia. $\mathrm{Br} \mathrm{J}$ Haematol 2008;141(2):133

4 Özkaya H, Aydemir G, Akcan AB. et al. Carbamazepineinduced red Blood cell aplasia: a case report. Turk J Haematol 2012;29(2):195-196

5 Paul G, Sood P, Berry A, Paul BS. Pure red cell aplasia with phenytoin following traumatic brain injury. Neurol India 2011;59(1):69-70 
6 Chandra Sekhar C, Ramana Reddi V, Srinivas B, Naik KR. Pure red cell aplasia associated with carbamazepine. J Assoc Physicians India 1998;46(7):655-656

7 Tagawa T, Sumi K, Uno R, Itagaki Y, Fujii F, Yamaguchi H. Pure red cell aplasia during carbamazepine monotherapy. Brain Dev 1997;19(4):300-302
8 Buitendag DJ. Pure red-cell aplasia associated with carbamazepine. A case report. S Afr Med J 1990;78(4):214-215

9 Medberry CAIII, Pappas AA, Ackerman BH.Carbamazepine and erythroid arrest. Drug Intell Clin Pharm 1987;21(5):439-441 